\title{
Influence of Land Use and Road Type on the Elemental Composition of Urban Dust in a Mexican Metropolitan Area
}

\author{
Anahi Aguilera ${ }^{1,2}$, Cynthia Armendariz ${ }^{1}$, Patricia Quintana ${ }^{3}$, \\ Felipe García-Oliva ${ }^{4}$, Francisco Bautista ${ }^{2 *}$ \\ 'Posgrado en Ciencias Biológicas, Escuela Nacional de Estudios Superiores, Morelia, \\ Universidad Nacional Autónoma de México, Morelia Michoacán, México \\ ${ }^{2}$ Laboratorio Universitario de Geofísica Ambiental, Centro de Investigaciones en Geografía Ambiental, \\ Universidad Nacional Autónoma de México, Morelia Michoacán, México \\ ${ }^{3}$ Departamento de Física Aplicada, Centro de Investigaciones y de Estudios Avanzados del Instituto \\ Politécnico Nacional, Unidad Mérida, Cordemex, Mérida, Yucatán, México \\ ${ }^{4}$ Instituto de Investigaciones en Ecosistemas y Sustentabilidad, Universidad Nacional Autónoma de México, \\ Morelia Michoacán, México
}

Received: 2 February 2018

Accepted: 23 April 2018

\begin{abstract}
The composition of urban dust can affect the health of urban populations, making it necessary to study its elemental composition and its sources. Our objectives were: a) to identify the main emission sources of heavy metals, and b) to evaluate the influence of land use and road type on the elemental composition of urban dust. 100 samples of urban dust taken in San Luis Potosí were analyzed using FRX. Descriptive statistics, Pearson's correlations coefficient, kriging interpolations, and analysis of variance were applied to the data. $\mathrm{Cu}$ and $\mathrm{Zn}$ were spatially associated with a metallurgical complex and, to a lesser extent, with an industrial park; Ca with fluorite and limestone industries, and $\mathrm{Si}$ with the surrounding soils. The highest concentrations of $\mathrm{Cu}, \mathrm{Zn}$, and $\mathrm{Ca}$ were found in mixed and industrial land uses. On the contrary, the highest concentrations of "natural elements" (Al, K, Si, Rb, and $\mathrm{Y}$ ) were found in developable land and residential areas. The highest contents of $\mathrm{Ca}$ were found in secondary and primary roads. The conclusions were: a) the metallurgical complex is the main source of $\mathrm{Cu}$ and $\mathrm{Zn}$, and b) the highest concentrations of $\mathrm{Cu}, \mathrm{Zn}$, and $\mathrm{Ca}$ were found in mixed and industrial land uses.
\end{abstract}

Keywords: heavy metals, urban pollution, lead, zinc, copper

*e-mail: leptosol@ciga.unam.mx 


\section{Introduction}

The World Health Organization (WHO) estimates that exposure to contaminated air causes 7 million deaths annually [1]. Urban dust is made up of pollutant particles emitted into the atmosphere, as well as particles from the surrounding soils, and is a type of short-term contamination [2]. Heavy metals are one of the most dangerous components of urban dust due to their toxicity, persistence, and bioaccumulation [3].

The sources of the heavy metals found in urban dust can be classified into two large groups: 1) of natural origin, from the resuspension and weathering of soil; and 2) of anthropic origin, from the burning of fossil fuels, industrial processes, and vehicles [3-6]. Identifying the sources of the particles helps design efficient measures for pollution control.

One way to identify the origin of heavy metals in urban dust is to analyze their frequency distribution; a Gaussian distribution usually suggests heavy metals of natural origin. A non-Gaussian distribution usually suggests heavy metals of anthropogenic origin [5, 7-9]. Spatial analysis, based on the elaboration of maps and the identification of the spatial distribution patterns of heavy metals, is another way to identify their sources, the most important of which are industrial and commercial zones, and roads with high vehicular traffic $[4,5,7,10-13]$.

The city of San Luis Potosí, Mexico, has a metallurgical complex that was highly contaminating in the past [14-16]. Indeed, $\mathrm{Pb}$ and $\mathrm{As}$ concentrations have been associated with health problems [17]. This motivated some control strategies in the 1990s: streets were paved, contaminated soil was removed, and a local smelter implemented control devices to decrease heavy metals emissions [18]. Recently, a restoration plan for the metallurgical wastes and contaminated soils was carried out inside the metallurgical complex.

However, the historical pollution remains in the environment and an electrolytic zinc refiner remains operational. In addition, recent years have seen the emergence of new industrial facilities and a constant growth of the urban network, which has created new pollution sources [19]. Due to these characteristics, the city of San Luis Potosí is a fertile field for the study of sources of contamination by heavy metals through statistical and spatial methods. The emission sources of heavy metals can be identified from the spatial distribution pattern because the higher concentrations are closer. This premise holds true because both point sources and mobile sources (urban land uses and vehicular traffic) emit pollutants at short distances.

The objectives of this work were: a) to identify the main emission sources of heavy metals using statistical techniques and spatial analysis; and b) to evaluate the influence of land use and road types on the presence of heavy metals in the urban dust of San Luis Potosí, Mexico.

\section{Material and Methods}

\author{
Study Site
}

The growth of the city of San Luis Potosí and its proximity to the head of the neighboring municipality, Soledad de Graciano Sánchez, have led to the formation of the Metropolitan Area of San Luis Potosí-Soledad de Graciano Sánchez (MASLP-SGS), the tenth largest metropolitan area of Mexico, based on its total economic output. Its population amounts to more than one million people [20].

The MASLP-SGS is located at $22.15^{\circ} \mathrm{N}$ and $100.98^{\circ} \mathrm{W}$ in the central region of Mexico, within the San Luis Potosí valley, at an average altitude of $1860 \mathrm{~m}$ a.s.l. Its climate is temperate and dry, with an annual rainfall of $372.9 \mathrm{~mm}$ and an average temperature of $16.8^{\circ} \mathrm{C}$. The MASLP-SGS is basically formed by alluvium, while the Sierra de San Miguelito, located to the west of the city, is formed by intrusive igneous rocks. The main types of soil are Cambisols and Durisols in the north and east of the MASLP-SGS; Durisols are characterized by a hard layer of silica. To the west of the metropolitan area, the soils consist mostly of Leptosols.

The city of San Luis Potosí is characterized by its metallurgical history (over a century old) and its extensive industrial development. About 250 factories are located in the industrial park south of the city [19]. The characterization of metallurgical waste has evidenced its high content of heavy metals. In 2014, this content exceeded the maximum limits allowed by the Mexican norm [21, 22]. The metallurgical wastes have been restored, but the historical pollution could remain, making it necessary to monitor this site.

\section{Sampling and Preparation of Samples}

In May 2016, systematic sampling was carried out in 100 sites. Urban dust samples were taken from a surface area of $1 \mathrm{~m}^{2}$ (Fig. 1) with the help of a brush and a plastic dustpan. The samples were packaged in plastic bags and labeled. Geographic location, land use, and road type were recorded in each sampling site. The samples were dried in the shade and at room temperature for one week, and then sieved with a $2 \mathrm{~mm}$ mesh.

The road types were classified into: 1) Rural: unpaved roads in sparsely populated areas; 2) Tertiary: single-lane streets; 3) Secondary: avenues, usually with two lanes and a median strip; and 4) Primary: large avenues and highways with more than three lanes in each direction.

The types of land use observed in the field were compared with the ones established by the Municipal Planning Institute of San Luis Potosí. The categories used in this article were: 1) Developable land (DL): unbuilt sites on the city outskirts or within the city; 2) Residential (RES): sites used almost exclusively for housing; 3) Mixed (MIX): zones of the city with two 


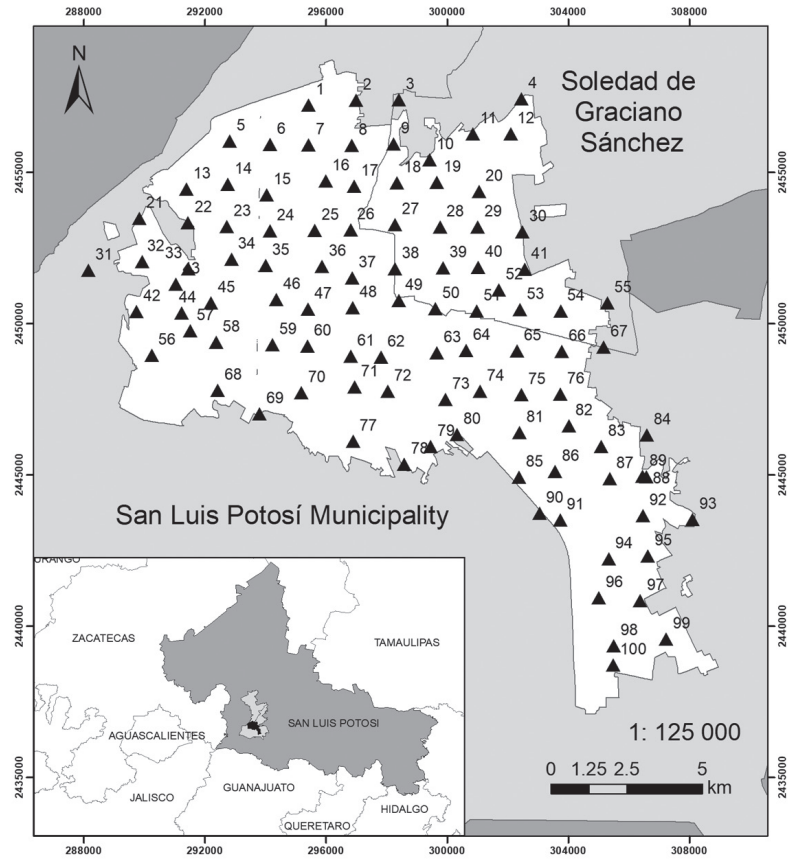

Fig. 1. Samples.

or more land uses, especially housing and services; and 4) Industrial (IND), corresponding to the industrial park south of the city and the metallurgical complex.

\section{Chemical Analysis of Urban Dust Samples}

The $\mathrm{pH}$ and electrical conductivity of the samples were measured in 1:10 soil-water extracts. Each measurement was made in triplicate and averaged.

The samples were pulverized with an agate mortar until obtaining a particle size of approximately $2 \mu \mathrm{m}$ to determine the concentrations of the following elements: aluminum $(\mathrm{Al})$, calcium $(\mathrm{Ca})$, iron $(\mathrm{Fe})$, potassium $(\mathrm{K})$, manganese $(\mathrm{Mn})$, sodium $(\mathrm{Na})$, silicon $(\mathrm{Si})$, titanium (Ti), rubidium $(\mathrm{Rb})$, strontium $(\mathrm{Sr})$, yttrium $(\mathrm{Y})$, copper $(\mathrm{Cu})$, lead $(\mathrm{Pb})$, and zinc $(\mathrm{Zn})$.

Subsequently, $0.4 \mathrm{~g}$ of dust were placed in a die of $5 \mathrm{~mm}$ in diameter and compressed at $9020 \mathrm{psi}$ (11 ton $\mathrm{cm}^{-2}$ ) for 5 minutes, without any chemical treatment or binder. The pellets were placed in a slide holder and sealed with polyester film (microfilm).

The measurements were made using a Jordan Valley EX-6600 energy-dispersive x-ray fluorescence spectrometer (FRX-DE) equipped with an $\mathrm{Si}$ (Li) detector with an active area of $20 \mathrm{~mm}^{2}$ and a resolution of $140 \mathrm{eV}$ at $5.9 \mathrm{keV}$, operating at a maximum of $54 \mathrm{keV}$ and $4800 \mu \mathrm{A}$. Each reading was repeated 5 times and averaged. The coefficient of variation of the five repetitions was calculated to assess the precision of the measurements. It has been reported that variations between 1 and $12 \%$ are considered analytically acceptable [23].

The calibration curve was made using the standards of the IGL series. The IGLsy-1 standard, which corresponds to a nepheline Syenite with a high content of $\mathrm{Al}$ and Si, was used as measurement control [24]. The measurements were made in the National Laboratory of Nano and Biomaterials (LANNBIO), at CINVESTAV Mérida, Yucatán. The use of the XRF-DE technique is common and appropriate in pollution studies (soils and dust) in which the concentrations of heavy metals are of the order of tenths and hundredths of $\mathrm{mg} / \mathrm{kg}[8,25]$, as was the case with this study. In addition, it is an easy, cheap, and quick technique.

\section{Identifying the Main Emission Sources}

A descriptive statistical analysis and multiple correlations between the variables were performed. The Pearson correlation coefficient measures the strength of a linear relationship between two quantitative variables $[4,26]$. Coefficients higher than 0.5 indicate a strong correlation; a positive sign indicates a directly proportional correlation, while a negative one indicates an inverse correlation.

According to Guvenç et al. [7], the frequency distribution, the differences between the average and the median, and the standard deviation can all be used as qualitative indicators to determine whether the concentration of a certain element in a city has been modified by anthropic activities. This work uses these criteria.

To delimit the spatial distribution of heavy metals, an experimental semivariogram was calculated from the data stored in a georeferenced database; the spatial dependence of each variable was determined using the following equation:

$$
\gamma(h)=\frac{1}{2 N(h)} \sum_{i=1}^{N(h)}\left[z\left(x_{i}\right)-z\left(x_{i}+h\right)\right]^{2}
$$

...where $\gamma(h)$ is the experimental semivariance value for all pairs at a lag distance $h$ (distance between pairs), $z\left(x_{i}\right)$ is the chemical element concentration at point $i$, and $x_{i}+h$ is the chemical element concentration of other points separated from $x_{i}$ by a discrete distance $h . N(h)$ is the number of pairs for $x_{i}$ and $x_{i}+h$. Based on the spatial structure $\gamma(h)$, the kriging estimator $z^{*}\left(x^{\prime}\right)$ for a variable in an unsampled site is defined as:

$$
z^{*}\left(x^{\prime}\right)=\sum_{i=1}^{n} \lambda_{i} z\left(x_{i}\right)
$$

...where $\lambda_{i}$ is the weight coefficient.

The experimental semivariogram was compared with theoretical semivariograms (spherical, exponential, Gaussian model, etc.) using Gamma Design software [27] in order to select the model with the best fit. A theoretical semivariogram was the most suitable model for interpolation of data; it provides great 
robustness because it allows us to explain the spatial correlation between the sampled sites [12].

The interpolations performed were of the ordinary kriging type and were used to make the spatial distribution maps of the variables in ArcMap, version 9.3. It should be noted that, as with any interpolation method, some uncertainty is introduced into the results, which, therefore, should always be considered as estimates [28].

\section{Influence of Land Use and Road Type}

An analysis of variance was carried out for each chemical element to determine whether there are statistically significant differences $(p<0.05)$ between the types of land use and roads. When ANOVA assumptions were violated, the Kruskal-Wallis test was used [29] analysis of variance (ANOVA. All analyses were performed using the R-Project software, version 3.3.2.

\section{Results and Discussion}

\section{Main Emission Sources of Heavy Metals}

Heavy metals $(\mathrm{Cu}, \mathrm{Pb}$ and $\mathrm{Zn})$ showed a great variation and a markedly asymmetric frequency distribution (Table 1). On the other hand, the elements $\mathrm{Al}, \mathrm{K}, \mathrm{Si}, \mathrm{Rb}$, and Y showed a normal distribution, little variation, and a strong Pearson correlation coefficient between these elements. $\mathrm{Ca}, \mathrm{Fe}, \mathrm{Na}, \mathrm{Ti}, \mathrm{Sr}$, and $\mathrm{Mn}$ showed greater variation than the above-mentioned elements, and their frequency distributions were asymmetric.

According to Guvenç et al. [7], the concentrations of elements from anthropic sources are expected to be very variable between sampling points because their concentrations depend on the distance from the sources. These elements should have asymmetric frequency distributions and high coefficients of variation. On the contrary, concentrations of elements from natural sources are expected to be uniformly distributed following a normal frequency distribution [7].

Ihl et al. [8] successfully discriminated between elements of natural and anthropic origin based on the asymmetry of their probability distributions. A high correlation coefficient has also been associated with a common origin $[4,13,26,30]$, as was the case with the elements studied here (Table 2).

Based on these criteria, heavy metals showed a predominantly anthropic origin, as indicated by their markedly asymmetric frequency distributions and their high coefficients of variation. $\mathrm{Cu}$ and $\mathrm{Zn}$ showed a strong and positive correlation between both elements

Table 1. Descriptive statistics of all studied variables..

\begin{tabular}{|c|c|c|c|c|c|c|c|c|}
\hline & \multirow{2}{*}{$\mathrm{pH}$} & \multirow{2}{*}{$\mathrm{EC}(\mu \mathrm{S})$} & \multicolumn{6}{|c|}{ Minor elements (mg/kg) } \\
\hline & & & $\mathrm{Cu}$ & $\mathrm{Pb}$ & $\mathrm{Rb}$ & $\mathrm{Sr}$ & Y & $\mathrm{Zn}$ \\
\hline Average & 8.7 & 361.5 & 134.7 & 208.0 & 132.9 & 100.9 & 45.9 & 402.5 \\
\hline Median & 8.7 & 263.7 & 86.6 & 162.8 & 130.4 & 97.7 & 46.3 & 207.4 \\
\hline SD & 0.6 & 320.0 & 157.9 & 158.8 & 44.8 & 36.3 & 14.8 & 630.2 \\
\hline $\mathrm{CV}$ & 0.1 & 0.9 & 1.2 & 0.8 & 0.3 & 0.4 & 0.3 & 1.6 \\
\hline Minimum & 7.5 & 93.9 & 23.2 & 58.9 & 12.2 & 19.2 & 5.8 & 12.7 \\
\hline Maximum & 10.9 & 2150.0 & 1058.7 & 1070.1 & 228.3 & 292.3 & 86.1 & 4426.4 \\
\hline Skewness & 3.4 & 14.3 & 14.6 & 10.5 & -0.2 & 8.0 & 0.1 & 17.1 \\
\hline \multirow[t]{3}{*}{ Kurtosis } & 4.3 & 30.8 & 31.2 & 18.8 & -0.9 & 16.8 & -0.4 & 41.4 \\
\hline & \multicolumn{8}{|c|}{ Major elements (\%) } \\
\hline & $\mathrm{Al}$ & $\mathrm{Ca}$ & $\mathrm{Fe}$ & K & $\mathrm{Mn}$ & $\mathrm{Na}$ & $\mathrm{Si}$ & $\mathrm{Ti}$ \\
\hline Average & 9.0 & 11.4 & 2.9 & 3.3 & 0.1 & 1.8 & 59.0 & 0.2 \\
\hline Median & 9.1 & 10.2 & 2.7 & 3.2 & 0.0 & 1.7 & 58.2 & 0.2 \\
\hline $\mathrm{SD}^{1}$ & 2.2 & 6.7 & 1.4 & 0.9 & 0.0 & 0.7 & 9.3 & 0.1 \\
\hline $\mathrm{CV}^{2}$ & 0.2 & 0.6 & 0.5 & 0.3 & 0.8 & 0.4 & 0.2 & 0.3 \\
\hline Minimum & 1.3 & 0.6 & 0.7 & 0.3 & 0.0 & 0.0 & 28.6 & 0.1 \\
\hline Maximum & 16.5 & 38.6 & 11.5 & 4.9 & 0.4 & 4.2 & 81.2 & 0.6 \\
\hline Skewness & 0.0 & 4.3 & 14.7 & -1.7 & 24.7 & 1.9 & -1.3 & 4.9 \\
\hline Kurtosis & 2.8 & 3.9 & 36.1 & 0.5 & 94.3 & 2.6 & 0.5 & 5.7 \\
\hline
\end{tabular}

${ }^{1} \mathrm{SD}=$ standard deviation, ${ }^{2} \mathrm{CV}=$ coefficient of variation.

Values in red indicate that the variables do not have a normal distribution, $\mathrm{n}=100$ 
Table 2. Pearson correlation coefficients for all the urban dust samples $(\mathrm{n}=100)$.

\begin{tabular}{|c|c|c|c|c|c|c|c|c|c|c|c|c|c|c|c|}
\hline & $\mathrm{CE}$ & $\mathrm{Al}$ & $\mathrm{Ca}$ & $\mathrm{Fe}$ & $\mathrm{K}$ & $\mathrm{Mn}$ & $\mathrm{Na}$ & $\mathrm{Si}$ & $\mathrm{Ti}$ & $\mathrm{Cu}$ & $\mathrm{Pb}$ & $\mathrm{Rb}$ & $\mathrm{Sr}$ & $\mathrm{Y}$ & $\mathrm{Zn}$ \\
\hline $\mathrm{pH}$ & -0.2 & 0.2 & -0.2 & 0.0 & 0.2 & 0.1 & -0.3 & 0.2 & 0.0 & -0.1 & 0.1 & 0.2 & -0.1 & 0.3 & 0.0 \\
\hline $\mathrm{CE}$ & & 0.1 & 0.0 & 0.0 & 0.1 & -0.1 & -0.1 & 0.1 & 0.1 & 0.0 & -0.1 & 0.1 & 0.0 & 0.1 & 0.0 \\
\hline $\mathrm{Al}$ & & & -0.8 & 0.0 & 0.8 & -0.1 & -0.6 & 0.8 & 0.4 & -0.1 & 0.0 & 0.8 & -0.5 & 0.9 & -0.1 \\
\hline $\mathrm{Ca}$ & & & & 0.2 & -0.9 & 0.2 & 0.6 & -0.9 & -0.1 & 0.1 & 0.0 & -0.8 & 0.7 & -0.8 & 0.1 \\
\hline $\mathrm{Fe}$ & & & & & -0.3 & 0.7 & 0.2 & -0.3 & 0.4 & 0.4 & 0.2 & -0.4 & -0.1 & -0.3 & 0.3 \\
\hline $\mathrm{K}$ & & & & & & -0.3 & -0.6 & 1.0 & 0.0 & -0.2 & 0.0 & 0.9 & -0.5 & 0.9 & -0.2 \\
\hline $\mathrm{Mn}$ & & & & & & & 0.2 & -0.3 & 0.2 & 0.4 & 0.1 & -0.3 & -0.1 & -0.2 & 0.3 \\
\hline $\mathrm{Na}$ & & & & & & & & -0.7 & 0.1 & 0.3 & 0.1 & -0.7 & 0.3 & -0.7 & 0.3 \\
\hline $\mathrm{Si}$ & & & & & & & & & -0.1 & -0.2 & 0.0 & 0.9 & -0.5 & 0.9 & -0.2 \\
\hline $\mathrm{Ti}$ & & & & & & & & & & 0.2 & 0.1 & 0.0 & 0.1 & 0.1 & 0.2 \\
\hline $\mathrm{Cu}$ & & & & & & & & & & & 0.4 & -0.3 & -0.1 & -0.2 & 1.0 \\
\hline $\mathrm{Pb}$ & & & & & & & & & & & & 0.0 & -0.1 & 0.0 & 0.4 \\
\hline $\mathrm{Rb}$ & & & & & & & & & & & & & -0.4 & 1.0 & -0.3 \\
\hline $\mathrm{Sr}$ & & & & & & & & & & & & & & -0.4 & -0.1 \\
\hline $\mathrm{Y}$ & & & & & & & & & & & & & -0.2 \\
\hline
\end{tabular}

Values in red indicate a strong correlation $(\mathrm{p}<0.01)$

$(\mathrm{r}=0.96)$, probably because both metals were used in the metallurgical complex northwest of the city. The copper refinery has been operating for 100 years, while the electrolytic zinc refinery has been in operation since 1982.

$\mathrm{Al}, \mathrm{K}, \mathrm{Si}, \mathrm{Rb}$, and $\mathrm{Y}$ must have a natural origin due to their normal frequency distributions, little variation, and strong correlation coefficients among them; "natural elements" from now on. The concentration of some elements, such as $\mathrm{Ca}, \mathrm{Fe}, \mathrm{Na}, \mathrm{Ti}, \mathrm{Sr}$, and $\mathrm{Mn}$ showed alterations produced by anthropic activities as evidenced by the asymmetric frequency distributions of these elements and their greater coefficients of variation with respect to the natural elements mentioned above. Therefore, these could be considered elements with a mixed origin. $\mathrm{Ca}$ and $\mathrm{Na}$ showed a strong negative correlation with the natural elements $(r>0.7)$, while $\mathrm{Ca}$ and $\mathrm{Sr}$ showed a strong positive correlation among them $(r=0.7)$.

Regarding spatial analysis, the experimental semivariograms were fitted to a bounded (spherical) model, which indicates that the covariance of the increments is finite, with the exception of the one corresponding to $\mathrm{Pb}$ (Table 3). It should be mentioned that, for all the variables, the first set of data pairs of the semivariogram contained more than 100 pairs, resulting in robust interpolations.

In general, the ranges were wide, indicating that there was spatial correlation up to $14-18 \mathrm{~km}$, with the exception of $\mathrm{Ca}$, for which a spatial correlation was determined at $20 \mathrm{~km}$. The Si range was $33 \mathrm{~km}$, which was greater than the maximum distance between sampling points. This makes the model unreliable, but it could also indicate that there is a spatial correlation beyond the studied area. It would be necessary to sample a larger area to confirm this.

For all the elements analyzed, the spatial structure (the variation explained by the model) was at least $50 \%$ (Table 3), at the limit of what is considered adequate for the explanatory power of a model.

The smoothing effect caused an overestimation of the smallest values and an underestimation of the largest ones, generating a simplified spatial pattern. Although the smoothing effect depends on the local properties of the data and is therefore not the same in all circumstances, it was considerable for this case (MASLP-SGS). In future studies, this effect could be reduced by using the sequential simulations of kriging [31].

The spatial analysis of the concentrations of the elements made it possible to identify, in broad strokes, their main emission sources, since the elements coming from anthropic activities generally follow a distribution pattern that is consistent with their sources [7].

\section{Lead $(\mathrm{Pb})$}

Due to measures implemented since the 1990s, the $\mathrm{Pb}$ concentrations have decreased in the areas surrounding the metallurgical complex. Nevertheless, concentrations higher than $400 \mathrm{mg} / \mathrm{kg}$, the maximum permissible limit in the Mexican legislation [21], were reported in 2006, with maximum values of $12,600 \mathrm{mg} / \mathrm{kg}$ [18]. 
Table 3. Geostatistical models from spatial analysis.

\begin{tabular}{|c|c|c|c|c|c|c||}
\hline Element & Model & $\mathrm{r}^{2}$ & $\begin{array}{c}\text { Spatial structure } \\
(\%)\end{array}$ & Range (km) & Nugget (\%) & $\mathrm{r}^{2} \mathrm{CV}^{*}$ \\
\hline $\mathrm{Ca}$ & Spherical & 0.8 & 50 & 20 & 50 & 0.03 \\
\hline $\mathrm{Si}$ & Spherical & 0.8 & 50 & 32.8 & 50 & 0.07 \\
\hline $\mathrm{Cu}$ & Spherical & 0.9 & 55 & 17.4 & 45 & 0.07 \\
\hline $\mathrm{Pb}$ & Exponential & 0.8 & 50 & 17.9 & 50 & 0.08 \\
\hline $\mathrm{Zn}$ & Spherical & 0.9 & 56 & 15.3 & 44 & 0.08 \\
\hline
\end{tabular}

In 2015, no values higher than $400 \mathrm{mg} / \mathrm{kg}$ were observed [32], but in the present study, whose samples were taken in May 2016, Pb concentrations higher than $400 \mathrm{mg} / \mathrm{kg}$ were found not only in the areas immediately surrounding the metallurgical complex but also at a distance of up to $7 \mathrm{~km}$ (Fig. 2). Their spatial distribution drew a circular pattern very close to the metallurgical complex and also along a strip that passes through the city center.

This suggests that there could be two main sources of $\mathrm{Pb}: 1)$ the metallurgical complex and 2) the vehicular traffic in the city center (Fig. 2). Previous studies have reported high levels of $\mathrm{Pb}$ sulfates clumped with As, $\mathrm{Zn}, \mathrm{Fe}$, and $\mathrm{Cu}$, due to emissions of the metallurgical complex $[14,15]$. The winds and the semi-desert climate of the area favor the re-suspension and transportation of the polluted dust to the adjacent lands.
Perez-Vazquez et al. [32] classified the city center as a location within the city of San Luis Potosí with heavy vehicular traffic. Hui et al. [30] also associated the concentrations of $\mathrm{Pb}$ to vehicular traffic in roadside soils along a highway in China: the concentrations of $\mathrm{Pb}$ were the highest along the segment with the highest traffic volume.

In accordance with the spatial distribution of $\mathrm{Pb}$ (Fig. 2), a third source of this metal could be the industrial park. This area presented intermediate concentrations of $\mathrm{Pb}$, and there is evidence of lead emissions from previous research. Aragón-Piña et al. [16] attributed the concentrations of $\mathrm{Pb}$ to the smelting of calcines and the recycling of batteries in atmospheric samples from the industrial park. The particles identified were mainly lead sulfates [16].

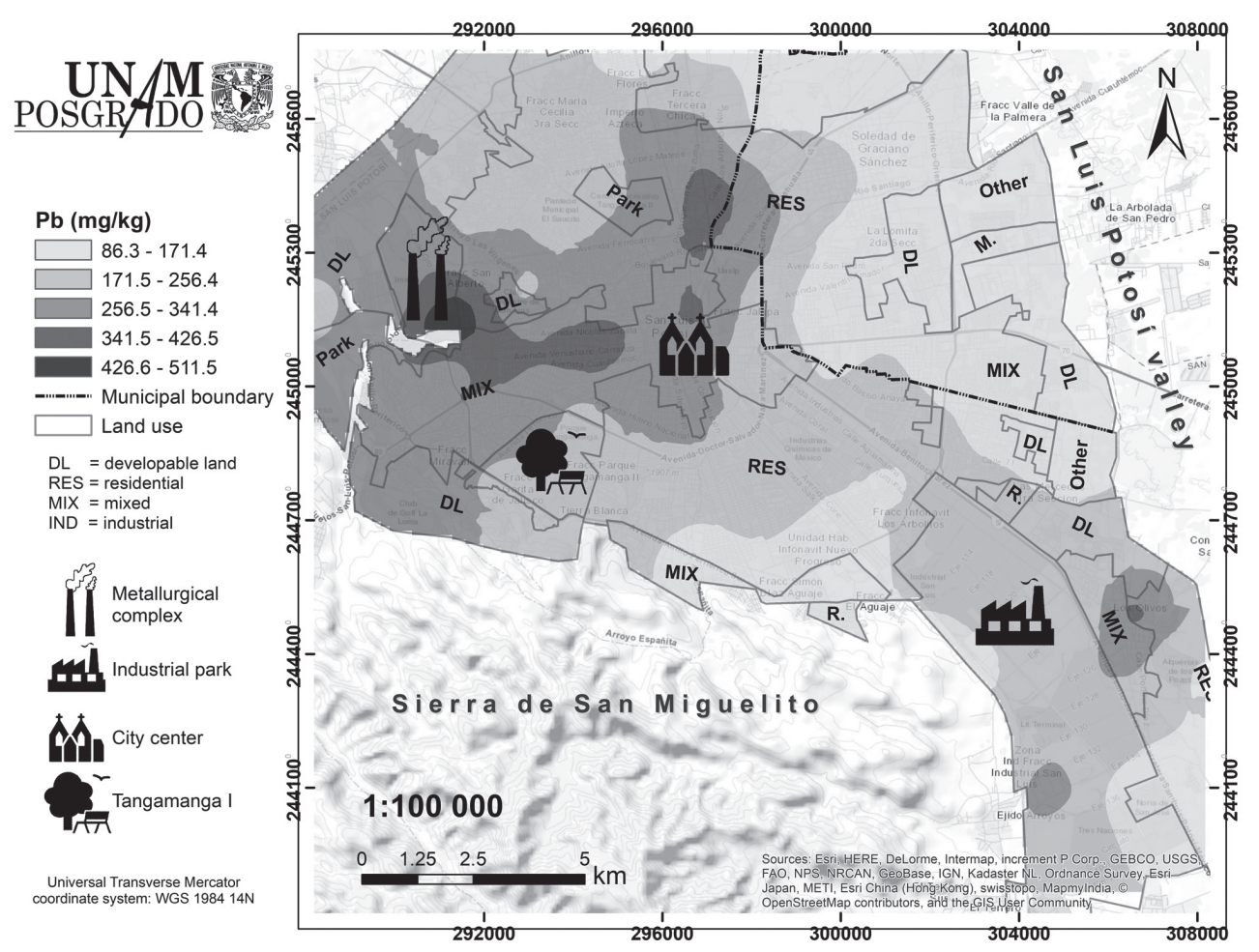

Fig. 2. Pb. 


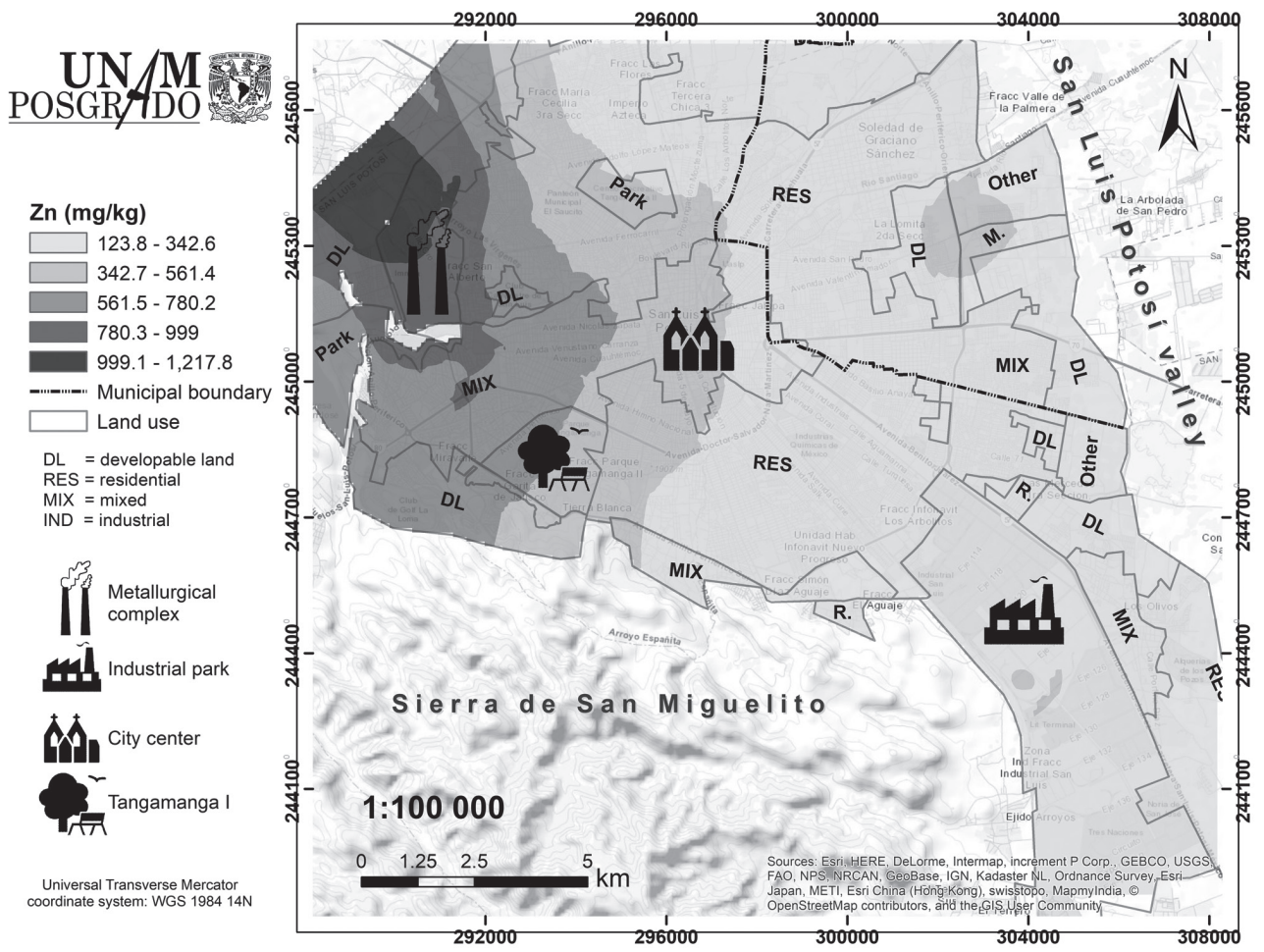

Fig. 2. Zn.

Zinc

The map for $\mathrm{Zn}$ shows that the highest concentrations of this metal were located north of the metallurgical complex and that they decreased as the distance to the complex increased (Fig 3). This spatial distribution suggests the possibility that the main source of $\mathrm{Zn}$ is located in this area and it is related to the activities of the metallurgical complex.

\section{Copper}

The map for $\mathrm{Cu}$ shows an inverse relationship between the concentration of this metal and the distance to the metallurgical complex (Fig. 4). The highest concentrations were found around the metallurgical complex and decreased with distance, mainly toward the East. This spatial pattern suggests that the main contribution of $\mathrm{Cu}$ comes from metallurgical activities. In fact, previous studies have found particles of metallic $\mathrm{Cu}$, and clumps of $\mathrm{Cu}$ and other metals, in sites close to the metallurgical complex $[14,15]$.

There seems to be another significant source of $\mathrm{Cu}$ in the industrial park. The map shows a slightly darker area that could be related to emissions of $\mathrm{Cu}$, increasing the concentration of this metal in the local environment. Aragón-Piña et al. [16] identified metallic $\mathrm{Cu}$ particles emitted by bronze smelting processes carried out in the industrial park. They reported $\mathrm{Cu}$ concentrations of $3.31 \mu \mathrm{g} / \mathrm{m}^{3}$, whereas the permissible concentration was $0.6 \mu \mathrm{g} / \mathrm{m}^{3}$.
Silicon

Si was selected from the natural elements to analyze its spatial distribution. The results showed that the highest concentrations of $\mathrm{Si}$ were located north of the MASLP-SGS, in an area with little urban development and in the presence of local vegetation and unpaved roadways (Fig. 5). These characteristics are associated with an environment with little anthropic intervention; the action of wind and of the air currents induced by the transit of vehicles and people suspend surface soil particles and move them to nearby sites.

The second area with a high content of $\mathrm{Si}$ surrounded the northern and eastern parts of the study area, toward the San Luis Potosí Valley. It should be remembered that the soils adjacent to this area are Cambisols and Durisols, the latter of which are characterized by having a high content of silica, which supports the hypothesis that the type of soil significantly influences the concentration of $\mathrm{Si}$ in urban dusts.

\section{Calcium}

The mixed origin of the concentrations of $\mathrm{Ca}$, previously identified, and the presence of industries that use this element in the study area were the main reasons to study its spatial distribution. The findings were very clear and indicated that the highest concentrations of this element were spatially related to the location of the limestone and fluorite industries (Fig. 6). Furthermore, 


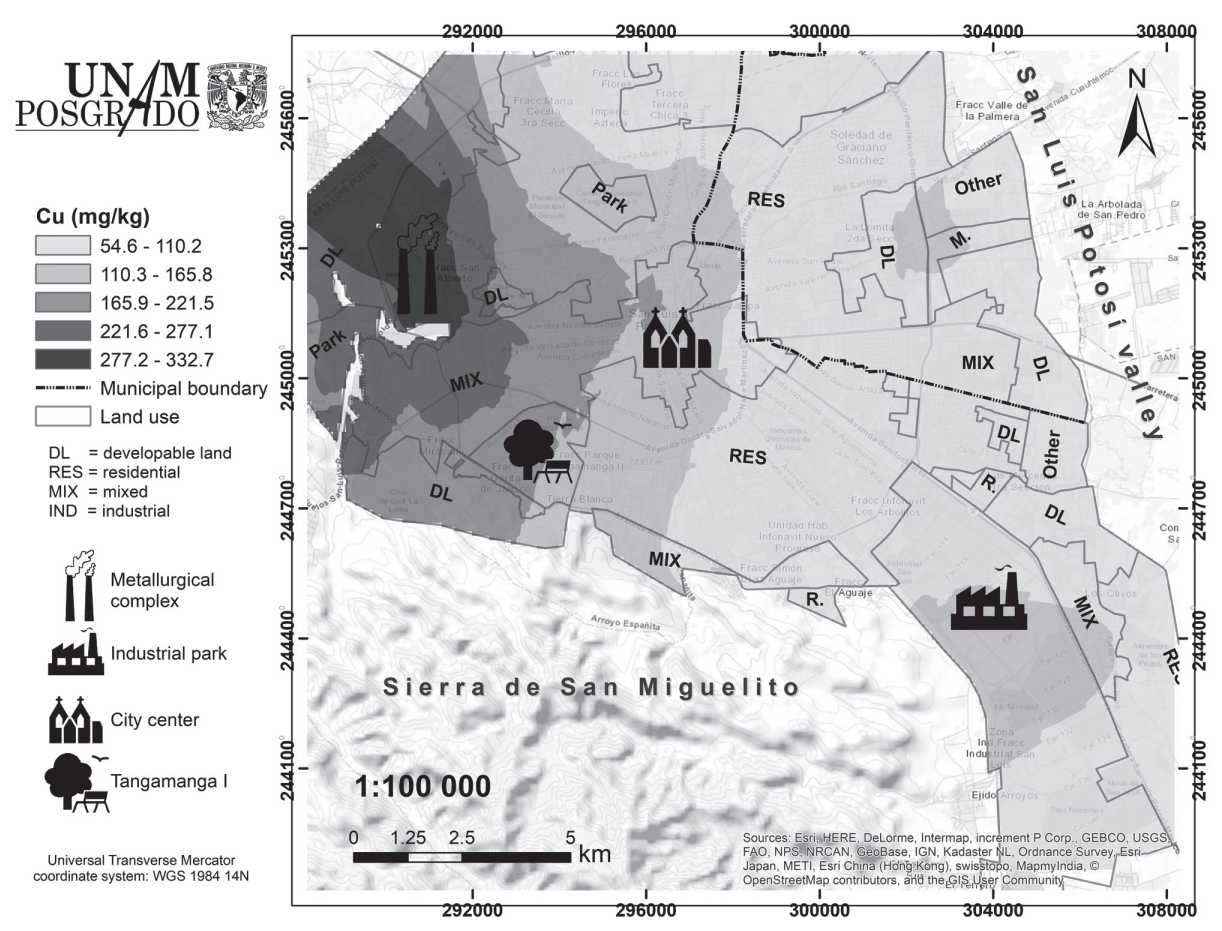

Fig. 4. Cu.

relatively high concentrations were found in the south of the city, along the peripheral road from the industrial park to Tangamanga I park.

These findings were consistent with those obtained by Aragón-Piña et al. [16], who observed an abundance of fluorite particles in the air of the industrial park. Moreover, these particles were also found in samples taken in Tangamanga I park, which indicates that the industrial park has a great influence on the presence of fluorite particles in the city.

As the results of this research confirm, the use of spatial distribution patterns to identify the main emission sources of heavy metals may work well in other study sites, especially in places where the sources are not very diverse and there are only a few main ones.

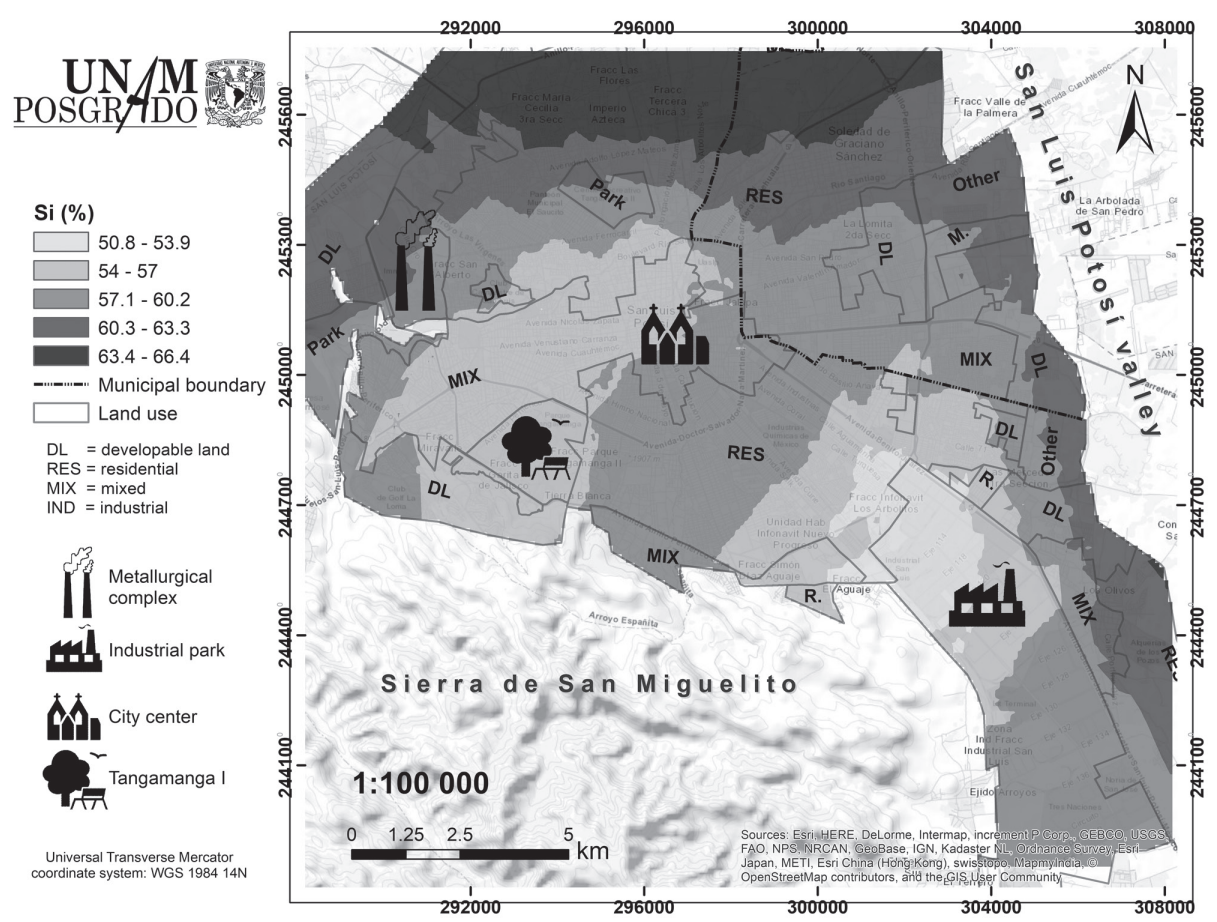

Fig. 5. Si. 


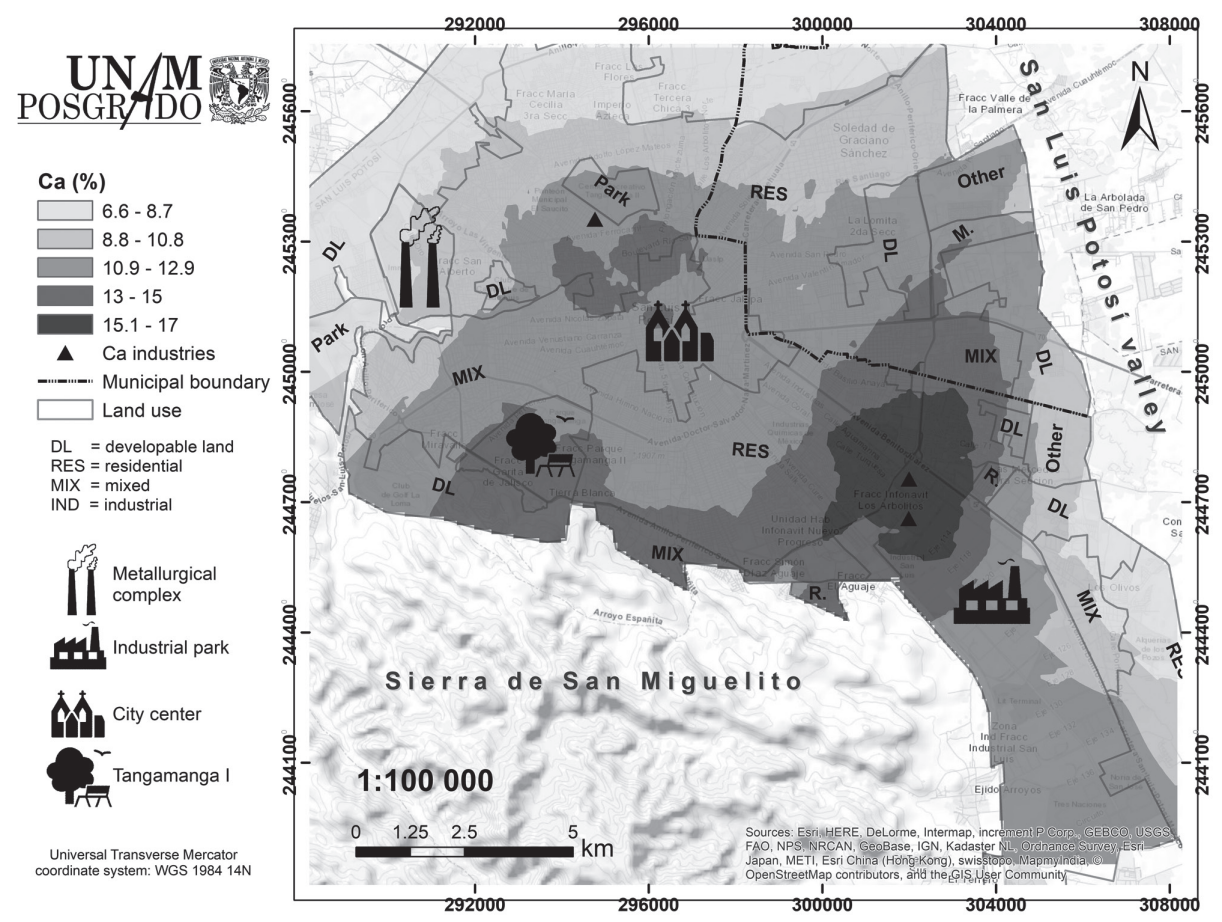

Fig. 6. Ca.

Influence of Land Use and Road Type on Contamination with Heavy Metals

\section{Heavy Metals}

According to the Kruskal-Wallis test, the MIX use had higher concentrations of $\mathrm{Cu}$ and $\mathrm{Zn}$ with respect to other land uses (Fig. 7). As the mixed use mainly has houses and shops, this result agrees with the ones from other studies that have found the highest concentrations of heavy metals in commercial areas [5, 13].

On the other hand, the lowest concentrations of heavy metals appeared in the DL and RES land uses. In the same way, Fang et al. [6] observed the lowest concentrations of $\mathrm{Zn}, \mathrm{Pb}$, and $\mathrm{Cu}$ in the residential district and concluded that the street dust of this district was less affected by metal pollution due to human activities.

As mentioned before, previous research in this study site identified $\mathrm{Cu}$ and $\mathrm{Zn}$ particles suspended in the air in areas adjacent to the metallurgical complex $[14,15]$, which is located to the north of the MIX land use. Indeed, the highest concentrations of heavy metals were found in the metallurgical complex area; they are represented as outliers in Fig. 7. The action of the wind may have moved this material to the surrounding areas, where it deposited on the surface.

In the case of $\mathrm{Pb}$, there were no statistically significant differences between land uses, which makes the analysis more complex. Fang et al. [6] also found a complex source of $\mathrm{Pb}$ in urban dust from Wuhu, China. This suggests that $\mathrm{Pb}$ is an element commonly related with multiple sources: industrial activities, vehicular exhaust emissions or non-engine combustion sources, and agriculture, for example [4, 33].

$\mathrm{Pb}$ has been considered the most problematic heavy metal in the city of San Luis Potosi [34] due to the high levels found in soils and in the blood of local children
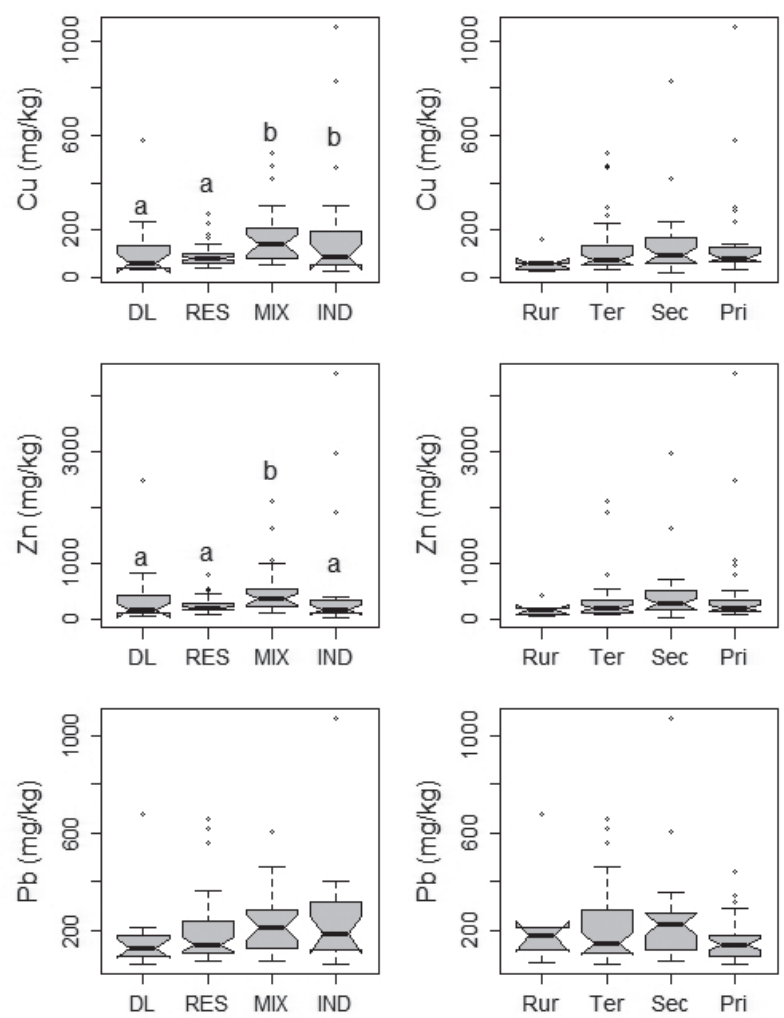

Fig. 7. Heavy metals. 
[18]. Furthermore, it has been associated with health problems, such as attention deficit disorder in children living in the Morales neighborhood, adjacent to the metallurgical complex [35]. Thus, continuing to monitor $\mathrm{Pb}$ concentrations is a matter of great importance in this metropolitan area.

Regarding road type, no statistically significant differences in heavy metal concentrations were found (Fig. 7). This could indicate that the main source of heavy metals in MASLP-SGS is not automotive vehicles. Otherwise, the highest concentrations would have been found in primary and secondary roads.

It is important to underline that there are few efforts for cleaning up the streets: main avenues are cleaned up by the municipality, while all other tertiary roads are cleaned by the residents. Only in some commercial zones are streets cleaned regularly. Thus, urban dust here represents a type of short- to medium-term contamination.

\section{Natural Elements}

The concentration of natural elements such as $\mathrm{Al}$, $\mathrm{K}, \mathrm{Si}, \mathrm{Rb}$, and $\mathrm{Y}$ decreased as the land use went from more transformed to less transformed types, in the order of DL $>$ RES $>$ MIX-IND, with statistically significant differences. The results suggest that the urban dusts found on the streets of areas with DL and RES uses must come mainly from the surrounding soils (Fig. 8). In contrast, the dust collected in areas with MIX and IND uses was composed of particles from the adjacent soils and from other anthropic sources (industries, shops, etc.), which translates into a lower concentration of $\mathrm{Al}, \mathrm{K}, \mathrm{Si}, \mathrm{Rb}$, and $\mathrm{Y}$.

The distribution of land uses in the MASLP-SGS is related to the presence of different types of soil and geological environments: while the DL and RES uses are closer to Cambisols and Durisols found in the San Luis Potosí valley, the MIX and IND uses are associated with Leptosols found in the Sierra de San Miguelito. This suggests that the type of soil could also influence the concentrations of $\mathrm{Al}, \mathrm{K}, \mathrm{Si}, \mathrm{Rb}$, and $\mathrm{Y}$ in areas with different land uses.

Regarding the road type, the concentrations of $\mathrm{Al}, \mathrm{K}, \mathrm{Si}, \mathrm{Rb}$, and $\mathrm{Y}$ (which come from soils) in urban dust were higher in rural and tertiary roads with respect to secondary and primary roads (Fig. 8). This strengthens the hypothesis of a natural origin of these elements.

\section{Calcium}

From the elements classified by their mixed origin and discussed in this article, only the contents of $\mathrm{Ca}$ and $\mathrm{Na}$ were statistically significantly different by land use and road type. The following relationship was found: DL $<$ RES-MIX-IND, with statistically significant differences (Fig. 9). The highest content of $\mathrm{Ca}$ was found in areas with industrial use.
As a matter of fact, the sample with the highest content of this element was collected very close to the fluorite mine. This agrees with the results obtained by Aragón-Piña et al. [16], who recorded high concentrations of calcium sulfates and fluorite coming from industrial park waste.

Furthermore, it was found that the content of $\mathrm{Ca}$ increased in the following way: $\operatorname{Rur}<$ Ter $<$ Sec-Pri, with statistically significant differences (Fig. 9). Ca has been referred to as an element associated with vehicular traffic [36], and the results of this study support this notion.

The use of $\mathrm{Ca}$, or of compounds that contain it, in the
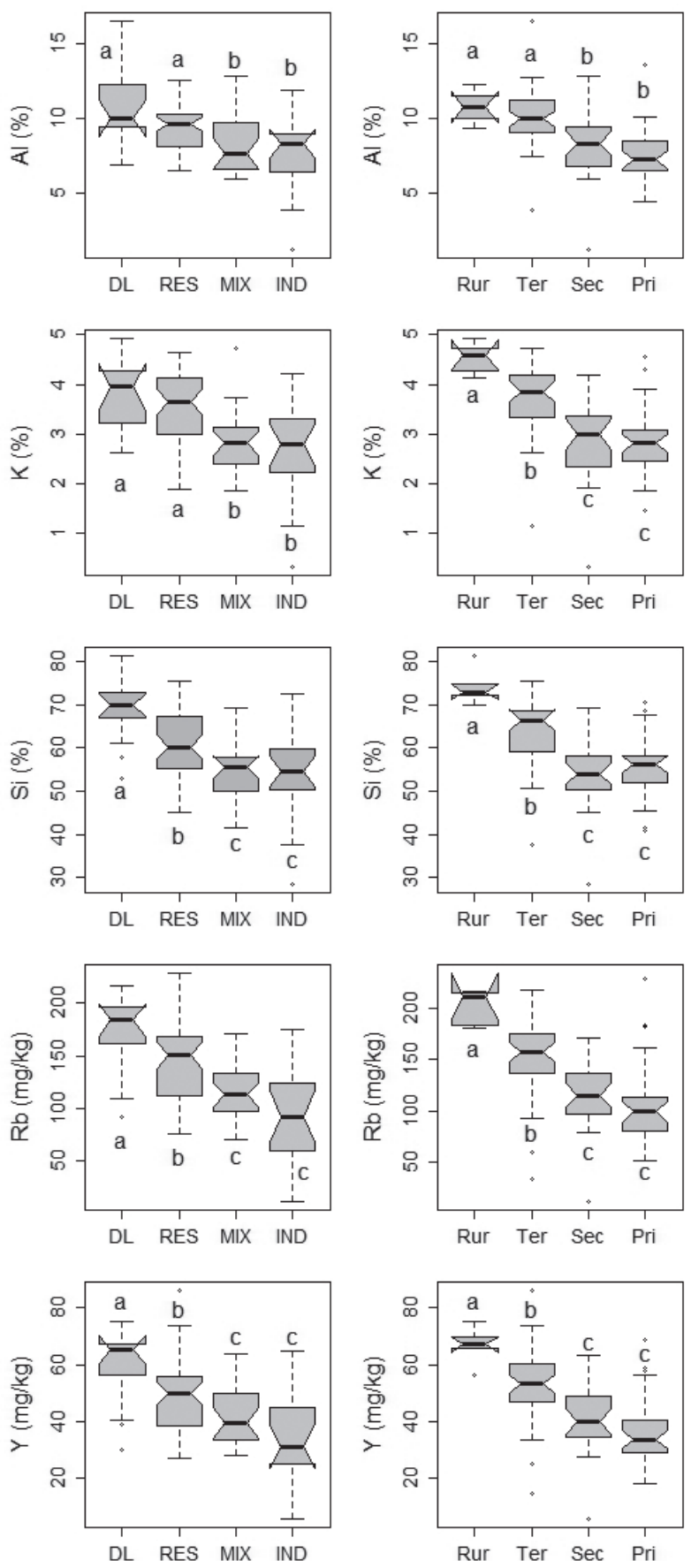

Fig. 8. Natural elements. 

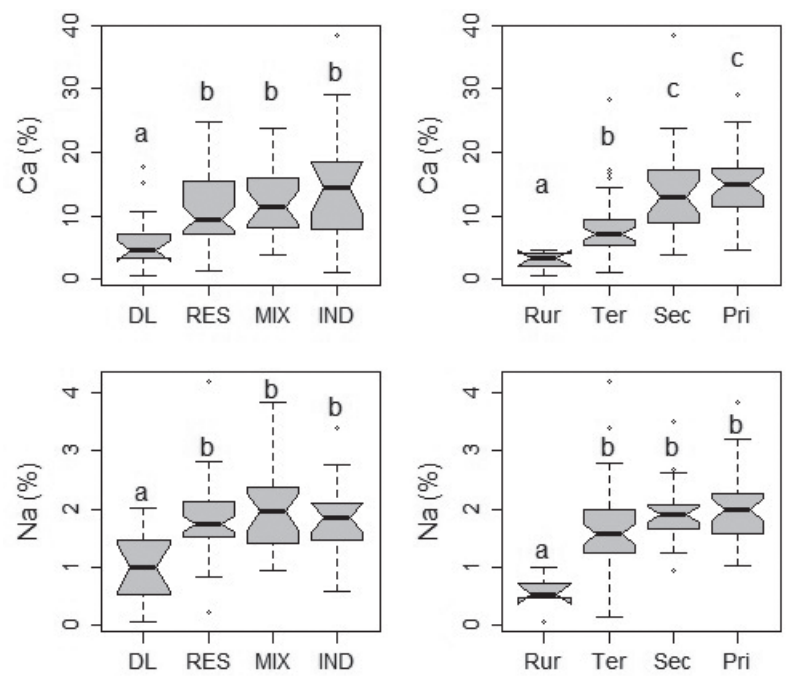

Fig. 9. $\mathrm{Ca}$ and $\mathrm{Na}$.

refinement of gasoline, in car radiators, air conditioners, etc., may be the reason for the increase in concentration of $\mathrm{Ca}$ in the busiest roads, such as secondary and primary roads, with respect to rural and tertiary roads.

The generation of spherical calcium phosphate particles has been observed in industries that employ used automotive oil as fuel [16]; thus, cars that do not work properly and burn their oils could be releasing calcium residues to the roads.

These analyses made it possible to inquire about the effect of land uses and road types on the elemental composition of urban dust. In the content of $\mathrm{Ca}$, analyses of variance complemented the spatial interpolation and gave some extra information. They suggested a contribution of the vehicles to the content of $\mathrm{Ca}$, which had not appeared in the map.

\section{Conclusions}

The highest concentrations of $\mathrm{Cu}$ and $\mathrm{Zn}$ were found in the metallurgical complex and, to a lesser extent, in the industrial park. The concentration of Si was associated with the surrounding soils, while the concentration of $\mathrm{Ca}$ was spatially related to the fluorite and limestone industries.

The highest concentrations of $\mathrm{Cu}, \mathrm{Zn}$, and $\mathrm{Ca}$ were found in areas with urban land uses with high anthropic intervention (mixed and industrial). The highest concentrations of $\mathrm{Pb}$ were found together with the metallurgical residues. In areas with residential and developable land use, urban dust mostly contained Al, $\mathrm{K}, \mathrm{Si}, \mathrm{Rb}$, and $\mathrm{Y}$.

By considering the road types, it was possible to identify the elements that are related to traffic flow, as was the case with $\mathrm{Ca}$. The highest concentrations of this element were found in the busiest roads: secondary and primary. In contrast, the concentrations of natural elements decreased in the busiest roads, since their source was not automotive vehicles but the surrounding soils.

The combined use of statistical and spatial techniques allowed for the identification of the elements' origin (natural or anthropic), and to some extent their main sources. New interpolation methods and mathematical models should be tested in order to better predict heavy metals' concentrations at unsampled locations.

\section{Acknowledgements}

Thank you to the National Council of Science and Technology for the financial support of project CB2011-01-169915, and to the project PAPIIT IA203713. Thank you to José Luis Cortés, Marco Anyelo Cazarez Barboza, Alexander Sanchez, Carmen Delgado, and Daniel Aguilar for their help in the field and laboratory work. Anahi Aguilera appreciates the economic support of CONACYT for the master's program fellowship.

\section{Conflict of Interest}

The authors declare no conflict of interest.

\section{References}

1. WORLD HEALTH ORGANIZATION (WHO). 7 million premature deaths annually linked to air pollution. World Health Organization (WHO). 2014, March.

2. BAUTISTA F., CRAM HEYDRICH S., SOMMER CERVANTES I. Suelos. In F. Bautista, J. L. Palacio, \& H. Delfín (Eds.), Técnicas de muestreo para manejadores de recursos naturales ( $2^{\text {nd }}$ ed., 227). Universidad Nacional Autónoma de México. 2011.

3. TCHOUNWOU P.B., YEDJOU C.G., PATLOLLA A.K., SUTTON D.J. Heavy Metals Toxicity and the Environment. National Institutes of Health. 101, 1, 2012.

4. CHEN H., LU X., LI L.Y., GAO T., CHANG Y. Metal contamination in campus dust of Xi'an, China: A study based on multivariate statistics and spatial distribution. Science of the Total Environment. 484 (1), 27, 2014.

5. LI H.H., CHEN L.J., YU L., GUO Z.B., SHAN C.Q., LIN J.Q., GU Y.G., YANG Z.B., YANG Y.X., SHAO J.R., XUE M.Z., CHENG Z. Pollution characteristics and risk assessment of human exposure to oral bioaccessibility of heavy metals via urban street dusts from different functional areas in Chengdu, China. Science of the Total Environment. 586, 1076, 2017.

6. FANG F., LI Y., LIN Y., XU M. Grain-size distribution and chemical speciation of heavy metals in Chinese street dust. Pol. J. Environ. Stud. 26 (4), 1501, 2017.

7. GUVENÇ N., ALAGHA O., TUNCEL G. Investigation of soil multi-element composition in Antalya, Turkey. Environment International. 29 (5), 631, 2003.

8. IHL T., BAUTISTA F., CEJUDO RUÍZ F. R., DELGADO M. DEL C., QUINTANA OWEN P., AGUILAR D., GOGUITCHAICHVILI A. Concentration of toxic elements in topsoils of the metropolitan area of Mexico 
city: A spatial analysis using ordinary kriging and indicator kriging. Revista Internacional de Contaminacion Ambiental. 31 (1), 47, 2015.

9. ALI M.U., LIU G., YOUSAF B., ABBAS Q., ULLAH H., MUNIR M.A.M., FU B. Pollution characteristics and human health risks of potentially (eco)toxic elements (PTEs) in road dust from metropolitan area of Hefei, China. Chemosphere. 181, 111, 2017.

10. RODRÍGUEZ-SALAZAR M.T., MORTON-BERMEA O., HERNÁNDEZ-ÁLVAREZ E., LOZANO R., TAPIACRUZ V. The study of metal contamination in urban topSoils of Mexico City using GIS. Environmental Earth Sciences. 62 (5), 899, 2011.

11. DELGADO C., ISRADE I., BAUTISTA F., GOGICHAISHVILI A., CEJUDO R., MORALES J., GONZÁLEZ I. Metales pesados en suelos urbanos de Morelia, Michoacán: influencia del uso de suelo y del tipo de vialidad. Ciencia Nicolaita. 65, 120, 2015.

12. SÁNCHEZ-DUQUE A., BAUTISTA F., GOGUITCHAICHVILI A., CEJUDO-RUIZ R., REYES-LÓPEZ J.A., SOLÍS-DOMÍNGUEZ F.A., MORALES-CONTRERAS J.J. Evaluación de la contaminación ambiental a partir del aumento magnético en polvos urbanos - Caso de estudio para la ciudad de Mexicali, México. Revista Mexicana de Ciencias Geológicas. 32 (3), 501, 2015.

13. TRUJILLO-GONZÁLEZ J. M., TORRES-MORA M. A., KEESSTRA S., BREVIK E. C., JIMÉNEZ-BALLESTA R. Heavy metal accumulation related to population density in road dust samples taken from urban sites under different land uses. Science of the Total Environment. 553, 636, 2016.

14. ARAGÓN PIÑA A., TORRES VILLASEÑOR G., MONROY FERNÁNDEZ M., LUSZCZEWSKI KUDRA A., LEYVA RAMOS R. Scanning electron microscope and statistical analysis of suspended heavy metal particles in San Luis Potosi, Mexico. Atmospheric Environment. 34 (24), 4103, 2000.

15. ARAGÓN-PIÑA A., TORRES-VILLASEÑOR G., SANTIAGO-JACINTO P., MONROY-FERNÁNDEZ M. Scanning and transmission electron microscope of suspended lead-rich particles in the air of San Luis Potosi, Mexico. Atmospheric Environment. 36 (33), 5235, 2002.

16. ARAGÓN-PIÑA A., CAMPOS-RAMOS A. A., LEYVARAMOS R., HERNÁNDEZ-ORTA M., MIRANDAORTIZ N., LUSZCZEWSKI-KUDRA A. Influencia de emisiones industriales en el polvo atmosférico de la ciudad de San Luis Potosí, México. Rev. Int. Contam. Ambient. 22 (1), 5, 2006.

17. DIAZ-BARRIGA F., SANTOS M.A., MEJIA J.J., BATRES L., YANEZ L., CARRIZALES L., VERA E., DEL RAZO L.M., CEBRIAN M.E. Arsenic and Cadmium Exposure in Children Living Near a Smelter Complex in San Luis Potosí, Mexico. Environmental Research. 62 (2), 242, 1993.

18. CARRIZALES L., RAZO I., TÉLLEZ-HERNÁNDEZ J.I., TORRES-NERIO R., TORRES A., BATRES L.E., CUBILLAS A.C., DÍAZ-BARRIGA F. Exposure to arsenic and lead of children living near a copper-smelter in San Luis Potosi, Mexico: Importance of soil contamination for exposure of children. Environmental research. 101 (1), 1, 2006.

19. PINEDA-MARTÍNEZ L.F., CARBAJAL N., CAMPOSRAMOS A., ARAGÓN-PIÑA A., GARCÍA A.R. Dispersion of atmospheric coarse particulate matter in the
San Luis Potosí, Mexico, urban area. Atmósfera. 27 (1), 5, 2014.

20. INEGI. Las zonas metropolitanas en México. Censos Económicos 2014. 2014.

21. SEMARNAT. NOM-147-SEMARNAT/SSA1-2004., Diario Oficial de la Federación 69. 2007.

22. PÉREZ I., MARTÍN-ROMERO F., ZAMORA O., GUTIERREZ-RUIZ M.E. Magnetic susceptibility and electrical conductivity as a proxy for evaluating soil contaminated with arsenic, cadmium and lead in a metallurgical area in the San Luis Potosi State, Mexico. Environ Earth Sci. 72, 1521, 2014.

23. PÉREZ-MARTÍNEZ I., ROMERO F.M. Uso de parámetros indirectos para la evaluación de la contaminación de suelos por metales pesados en una zona minera de San Luis Potosí , México. Boletín de la Sociedad Geológica Mexicana. 67 (1), 12, 2015.

24. LOZANO R., BERNAL J.P. Characterization of a new set of eight geochemical reference materials for XRF major and trace element analysis. Revista Mexicana de Ciencias Geológicas. 22 (3), 329, 2005

25. CORTÉS J.L., BAUTISTA F., QUINTANA P., AGUILAR D., GOGUICHAISHVILI A. The color of urban dust as an indicator of contamination by potentially toxic elements: the case of Ensenada, Baja California, Mexico. Revista Chapingo Serie Ciencias Forestales y del Ambiente. XXI (3), 255, 2015.

26. SAEEDI M., LI L.Y., SALMANZADEH M. Heavy metals and polycyclic aromatic hydrocarbons: Pollution and ecological risk assessment in street dust of Tehran. Journal of Hazardous Materials. 227-228, 9, 2012.

27. ROBERTSON G. GS+: Geostatistics for the Environmental Sciences. Gamma Design Software, Plainwell. Michigan, USA, 2008.

28. GUILLÉN M.T., DELGADO J., ALBANESE S., NIETO J.M., LIMA A., DE VIVO B. Environmental geochemical mapping of Huelva municipality soils (SW Spain) as a tool to determine background and baseline values. Journal of Geochemical Exploration. 109 (1-3), 59, 2011.

29. RUXTON G.D., BEAUCHAMP G. Some suggestions about appropriate use of the Kruskal-Wallis test. Animal Behaviour. 76 (3), 1083, 2008.

30. HUI Z., CAIQIU W., JIPING G., XUYIN Y., QIAO W., WENMING P., TAO L., JIE Q., HANPEI Z. Assessment of heavy metal contamination in roadside soils along the Shenyang-Dalian highway in liaoning province, China. Pol. J. Environ. Stud. 26 (4), 1539, 2017.

31. JUANG K.W., CHEN Y.S., LEE D.Y. Using sequential indicator simulation to assess the uncertainty of delineating heavy-metal contaminated soils. Environmental Pollution. 127 (2), 229, 2004.

32. PEREZ-VAZQUEZ F.J., FLORES-RAMIREZ R., OCHOA-MARTINEZ A.C., ORTA-GARCIA S.T., HERNANDEZ-CASTRO B., CARRIZALEZ-YAÑEZ L., PÉREZ-MALDONADO I. N. Concentrations of persistent organic pollutants (POPs) and heavy metals in soil from San Luis Potosí, México. Environmental monitoring and assessment. 187 (1), 4119, 2015.

33. LIU H., LIU G., ZHOU Y., HE C. Spatial Distribution and Influence Analysis of Soil Heavy Metals in a Hilly Region of Sichuan Basin. Pol. J. Environ. Stud. 26 (2), 725, 2017.

34. VARGAS MERGOLD A.V. La empresa metalúrgica Industrial Minera México en San Luis Potosí. Problemas 
ambientales con soluciones incoheretes. El Colegio de San Luis Potosí, A.C. 2016.

35. CALDERÓN J., NAVARRO M.E., JIMENEZCAPDEVILLE M.E., SANTOS-DIAZ M.A., GOLDEN A., RODRIGUEZ-LEYVA I., BORJA-ABURTO V., DÍAZ-BARRIGA F. Exposure to arsenic and lead and neuropsychological development in Mexican children. Environmental research. 85 (2), 69, 2001.

36. GÓRKA-KOSTRUBIEC B. The magnetic properties of indoor dust fractions as markers of air pollution inside buildings. Building and Environment. 90, 186, 2015. 